\title{
RESULTS REGARDING ON THE DYNAMICS OF THE ATTACK OF THE PATHOGEN PLASMOPARA VITICOLA IN THE CLIMATIC CONDITIONS OF THE YEARS 2019-2020, IN THE SEGARCEA WINE FARM-ARCHDIOCESE CRAIOVA, DOLJ COUNTY
}

\author{
Daiana Greta Dumitriu ${ }^{1 *}$, Rodi Mitrea ${ }^{1}$ \\ ${ }^{1}$ University of Caiova, Faculty of Horticulture, A.I.Cuza Street, no 13, Craiova, Dolj, Romania
}

Current Trends in

Natural Sciences

\section{Abstract}

The Archdiocese of Craiova owns 40ha cultivated with vines within the locality of Segarcea, the main varieties being both varieties for Merlot, Cabernet Sauvignon red wines, and varieties for white wines: Sauvignon Blanc, Tămăioasă Românească and Chardonnay.

Segarcea locality is located in an area with temperate-continental climate, where the average annual temperature is 11 degrees Celsius and the average amount of precipitation is about $510 \mathrm{~mm} /$ year, according to statistical data.

In the climatic conditions of 2019-2020, the National Phytosanitary Authority, through the Dolj Phytosanitary Office, issued warning bulletins based on the basic criteria: phenological, biological and ecological of the vine.

The phytopathogenic agent of the vine Plasmopara viticola, was monitored in terms of the evolution of the attack on the crop, in correlation with the climatic conditions and the way of reaction of the varieties to the attack of the phytopathogen was observed.

Keywords: climatic conditions, pathogens, vine

\section{INTRODUCTION}

In our country, the disease was first observed in 1887 (in the Buzău vineyards), but after Viala, it seems to have penetrated earlier, it being reported since 1881 in neighboring countries (Rădulescu et al., 1972).

The pathogen Plasmopara viticola is considered the most damaging disease of the vine, manifesting itself on the upper organs of the plant, but the most common is the attack on the leaves, with a welldefined symptom of stains undelemnii.

The damages caused by the pathogen Plasmopara viticola are very large, with remanence in the following years, the losses can vary depending on the climatic conditions of the respective year.

The attack of this phytopathogen on the vine culture increases the acidity, depreciating the quality of the harvest.

The epidemic character of the disease is conditioned by the aggressiveness and virulence of the pathogen, the stage of development of the pathogen, its speed of spread and the way of survival from one vegetation period to another, the number of pathogens (Mitrea, 2006).

Establishing the optimal terms for applying the treatments is done taking into account the recommended type of control and the type of disease (Roșca, 2018). 


\section{Current Trends in Natural Sciences}

Vol. 10, Issue 19, pp. 362-367, 2021

https://doi.org/10.47068/ctns.2021.v10i19.047

Current Trends in Natural Sciences (on-line)

ISSN: 2284-953X

Current Trends in Natural Sciences (CD-Rom)

ISSN: 2284-9521

ISSN-L: 2284-9521

ISSN-L: 2284-9521

Bădărău et al. (2007) recommends, in order to obtain high and good quality harvests, that the treatments against harmful organisms from the vine plantations be carried out in strict compliance with the recommended doses and application techniques.

In order not to appear forms of resistance to pathogens, it is recommended to alternate the products during the treatments, but with products that contain different active substances (Ianoși, 2002).

\section{MATERIALS AND METHODS}

In order to control the previously reported pest, in the Segarcea wine farm Archdiocese Craiova, 7 phytosanitary treatments were carried out both in 2019 and in 2020, according to the warning bulletins issued by the National Phytosanitary Authority, through the Dolj Phytosanitary Office and a number of products were applied under the treatment scheme shown in table 1.

Table 1. Treatment scheme applied in 2019 -2020 in the Segarcea wine farm, Craiova Archdiocese

\begin{tabular}{|c|c|c|c|c|c|}
\hline $\begin{array}{l}\text { No of } \\
\text { treatm } \\
\text { ents }\end{array}$ & Product used & Active substance $\%$ & Dose/ha & Target organism & Remarks \\
\hline 1 & $\begin{array}{l}\text { Dithane M45 } \\
\text { Captan }\end{array}$ & $\begin{array}{l}\text { Mancozeb }-80 \% \quad \text { and } \\
\text { hexamethylenetetramine }-<5 \% \text {. } \\
\text { Captan- } 80 \% \text {. }\end{array}$ & $\begin{array}{c}2 \mathrm{~kg} \\
1.25 \mathrm{~kg}\end{array}$ & $\begin{array}{l}\text { Plasmopara viticola } \\
\text { Plasmopara viticola }\end{array}$ & $\begin{array}{l}\text { Year } 2019 \\
\text { Year } 2020\end{array}$ \\
\hline 2 & $\begin{array}{l}\text { Ridomil Gold MZ } \\
68 \mathrm{WG} \\
\text { Ridomil Gold MZ } \\
68 \mathrm{WG}\end{array}$ & $\begin{array}{lll}\text { Mancozeb - } & 64 \% & \text { and } \\
\text { mefenoxam-4\%. } & & \\
\begin{array}{l}\text { Mancozeb - } \\
\text { mefenoxam-4\% }\end{array} & 64 \% & \text { and } \\
\end{array}$ & $\begin{array}{l}2.5 \mathrm{~kg} \\
2.5 \mathrm{~kg}\end{array}$ & $\begin{array}{l}\text { Plasmopara viticola } \\
\text { Plasmopara viticola }\end{array}$ & $\begin{array}{l}\text { Year } 2019 \\
\text { Year } 2020\end{array}$ \\
\hline 3 & $\begin{array}{l}\text { Ridomil Gold } \mathrm{MZ} \\
68 \mathrm{WG} \\
\text { Ridomil Gold } \mathrm{MZ} \\
68 \mathrm{WG}\end{array}$ & $\begin{array}{llll}\text { Mancozeb - } & 64 \% & \text { and } \\
\text { mefenoxam-4\%. } & & \\
\text { Mancozeb - } & 64 \% & \text { and } \\
\text { mefenoxam-4\%. } & & \end{array}$ & $\begin{array}{l}2.5 \mathrm{~kg} \\
2.5 \mathrm{~kg}\end{array}$ & $\begin{array}{l}\text { Plasmopara viticola } \\
\text { Plasmopara viticola }\end{array}$ & $\begin{array}{l}\text { Year } 2019 \\
\text { Year } 2020\end{array}$ \\
\hline 4 & $\begin{array}{l}\text { Mikal flash } \\
\text { Mikal flash }\end{array}$ & $\begin{array}{l}\text { Fosetyl }-50 \% \text { and folpet- } 25 \% \text {. } \\
\text { Fosetyl }-50 \% \text { and folpet- } 25 \% \text {. }\end{array}$ & $\begin{array}{l}3 \mathrm{~kg} \\
3 \mathrm{~kg}\end{array}$ & $\begin{array}{l}\text { Plasmopara viticola } \\
\text { Plasmopara viticola }\end{array}$ & $\begin{array}{l}\text { Year } 2019 \\
\text { Year } 2020\end{array}$ \\
\hline 5 & $\begin{array}{l}\text { Mikal flash } \\
\text { Mikal flash }\end{array}$ & $\begin{array}{l}\text { Fosetyl-50\% and folpet- } 25 \% \text {. } \\
\text { Fosetyl-50\% and folpet- } 25 \% \text {. }\end{array}$ & $\begin{array}{l}3 \mathrm{~kg} \\
3 \mathrm{~kg}\end{array}$ & $\begin{array}{l}\text { Plasmopara viticola } \\
\text { Plasmopara viticola }\end{array}$ & $\begin{array}{l}\text { Year } 2019 \\
\text { Year } 2020\end{array}$ \\
\hline 6 & $\begin{array}{l}\text { Funguran } \\
\text { Funguran }\end{array}$ & $\begin{array}{l}\text { Copper hydroxide }-77 \% \\
\text { Copper hydroxide }-77 \% \\
\end{array}$ & $2 \mathrm{~kg}$ & $\begin{array}{l}\text { Plasmopara viticola } \\
\text { Plasmopara viticola }\end{array}$ & $\begin{array}{l}\text { Year } 2019 \\
\text { Year } 2020 \\
\end{array}$ \\
\hline 7 & $\begin{array}{l}\text { Bouille } \\
\text { Bordelaise WDG } \\
\text { Bouille } \\
\text { Bordelaise WDG }\end{array}$ & $\begin{array}{l}\text { Neutralized copper sulphate - } \\
80 \% \text { and copper- } 20 \% \text {. } \\
\text { Neutralized copper sulphate }- \\
80 \% \text { and copper- } 20 \% \text {. }\end{array}$ & $5 \mathrm{~kg}$ & $\begin{array}{l}\text { Plasmopara viticola } \\
\text { Plasmopara viticola }\end{array}$ & $\begin{array}{l}\text { Year } 2019 \\
\text { Year } 2020\end{array}$ \\
\hline
\end{tabular}

The 7 treatments within the treatment scheme were applied on the following dates: 6.05.2019; 27.05.2019; 9.06.2019; 26.06.2019; 10.07.2019; 24.07.2019, 3.08.2019, and for the year 2020 the 7 treatments were applied to the following dates: $22.04 .2020 ; 23.05 .2020 ; 10.06 .2020 ; 24.06 .2020$; 11.07.2020; 28.07.2020; 9.08.2020.

The estimation of the attack produced by the micromicetes Plasmopara viticola, was made at the level of leaves and bunches, as the case may be, according to the methodologies used in the Forecast and Warning Stations. 


\section{Current Trends in Natural Sciences}

Vol. 10, Issue 19, pp. 362-367, 2021

https://doi.org/10.47068/ctns.2021.v10i19.047

Current Trends in Natural Sciences (on-line)

ISSN: 2284-953X

Current Trends in Natural Sciences (CD-Rom)

ISSN: 2284-9521

ISSN-L: 2284-9521

ISSN-L: 2284-9521

The frequency (F\%), the intensity (1\%) were established and the degree of attack (DA\%) was calculated, the collected data being processed according to the usual formulas.

\section{RESULTS AND DISCUSSION}

In the climatic conditions of the year 2019 - 2020, following the 7 treatments each year, as shown in table 2 and table 3, the degree of attack of the fungus Plasmopara viticola registered different values depending on the variety and the organ attacked.

The year 2019 but also the year 2020, were warm years but also with precipitations, which made the development of the pathogen Plasmopara viticola to be less obvious, and the 7 treatments applied during the vegetation period both in 2019 and in the year 2020, kept his attack under control.

Table 2. The biological efficacy of some products in combating manna in some grape varieties, in 2019

\begin{tabular}{|l|c|c|c|c|c|c|}
\hline \multirow{2}{*}{ Variety } & \multicolumn{7}{|c|}{ Attack on the leaf } & \multicolumn{2}{c|}{ Attack on the bunches } \\
\cline { 2 - 7 } & F\% & I\% & DA\% & F\% & I\% & DA\% \\
\hline Merlot & 20.41 & 6.70 & 1.36 & 12.83 & 5.61 & 0.72 \\
\hline $\begin{array}{l}\text { Cabernet } \\
\text { Sauvignon }\end{array}$ & 22.30 & 7.35 & 1.64 & 15.24 & 5.77 & 0.88 \\
\hline Chardonnay & 40.79 & 10.54 & 4.30 & 28.32 & 8.96 & 2.54 \\
\hline $\begin{array}{l}\text { Tămâioasă } \\
\text { Românească }\end{array}$ & 49.91 & 11.26 & 5.62 & 25.81 & 11.39 & 2.94 \\
\hline \begin{tabular}{l} 
Sauvignon Blanc \\
\hline
\end{tabular} & 35.30 & 9.15 & 3.23 & 24.01 & 7.41 & 1.78 \\
\hline
\end{tabular}

The incidence of the attack on leaves recorded values ranging from $20.41 \%$ in the Merlot variety to $49.91 \%$ in Tămâioasă Românească, while the virulence of the attack had values between $6.70 \%$ and $11.26 \%$ in the same varieties.

After calculating the degree of attack (DA\%), it can be seen that the varieties with the best reaction to the attack on the leaves of the Plasmopara viticola fungus were Merlot and Cabernet Sauvignon, at the opposite pole being the for white wines, in which the maximum value of the degree of atttack was 5.62\% Tămâioasă Românească.

The attack on the bunches manifested with a lower incidence and virulence,the maximum degree of attack being 2,94\% ( Tămâioasă Românească), and the minimum 0.72\% (Merlot).

Table 3. The biological efficacy of some products in combating manna in some grape varieties, in 2020

\begin{tabular}{|l|c|c|c|c|c|c|}
\hline \multirow{2}{*}{ Soi } & \multicolumn{3}{c|}{ Attack on the leaf } & \multicolumn{3}{c|}{ Attack on the bunches } \\
\cline { 2 - 7 } & F\% & I\% & DA\% & F\% & I\% & DA\% \\
\hline Merlot & 20.40 & 6.50 & 1.36 & 12.83 & 5.60 & 0.70 \\
\hline $\begin{array}{l}\text { Cabernet } \\
\text { Sauvignon }\end{array}$ & 22.30 & 7.34 & 1.64 & 15.24 & 5.77 & 0.88 \\
\hline Chardonnay & 40.79 & 10.50 & 4.30 & 28.32 & 8.96 & 2.54 \\
\hline $\begin{array}{l}\text { Tămâioasă } \\
\text { Românească }\end{array}$ & 49.89 & 11.24 & 5.60 & 25.81 & 11.39 & 2.93 \\
\hline $\begin{array}{l}\text { Sauvignon } \\
\text { Blanc }\end{array}$ & 35.30 & 9.10 & 3.23 & 24.02 & 7.41 & 1.78 \\
\hline
\end{tabular}


Current Trends in Natural Sciences (on-line)

ISSN: 2284-953X

Current Trends in Natural Sciences (CD-Rom)

ISSN: 2284-9521

ISSN-L: 2284-9521

ISSN-L: 2284-9521

The incidence of the attack on leaves recorded values ranging from $20.40 \%$ in the Merlot variety to $49.89 \%$ in Tămâioasă Românească, while the virulence of the attack had values between $6.50 \%$ and $11.24 \%$ in the same varieties.

After calculating the degree of attack (DA\%), it can be seen that the varieties with the best reaction to the attack on the leaves of the Plasmopara viticola fungus were Merlot and Cabernet Sauvignon, at the opposite pole being the for white wines, in which the maximum value of the degree of atttack was 5.60\% Tămâioasă Românească.

The attack on the bunches manifested with a lower incidence and virulence, the maximum degree of attack being $2.93 \%$ (Tămâioasă Românească), and the minimum 0.70\% (Merlot).

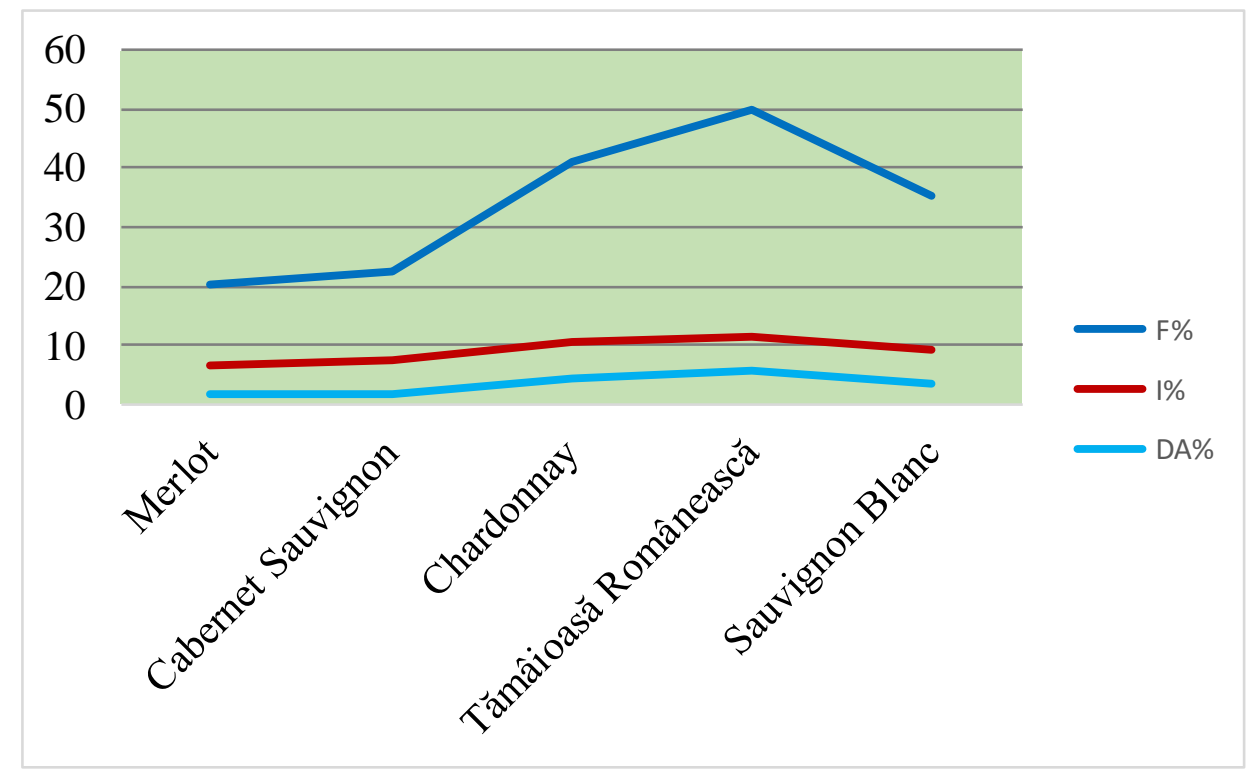

Figure 1. Manna attack on leaves in 2020

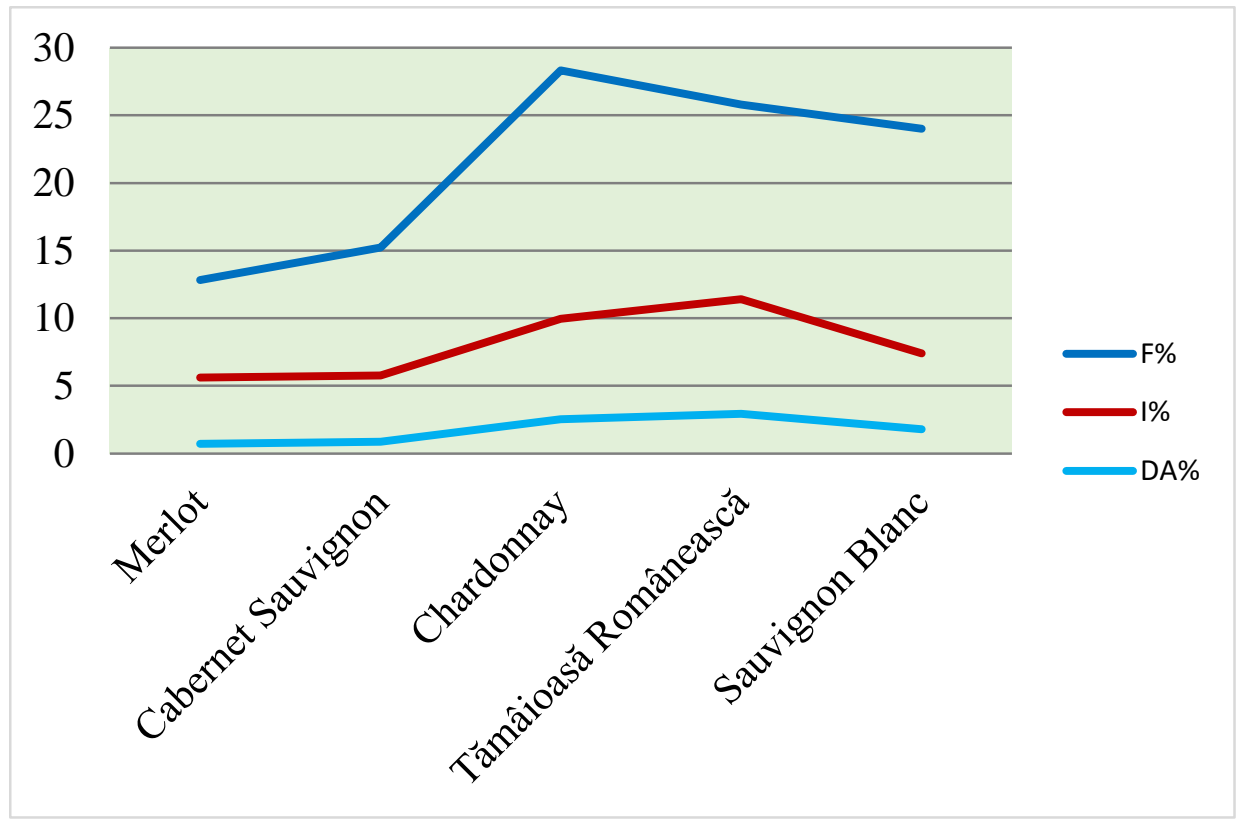

Figure 2. Manna attack on bunches in 2020 


\section{CONCLUSIONS}

The location of the experiments is characterized by ecopedological conditions favorable to the cultivation of vines but also to the development of the pathogen Plasmopara viticola.

The 5 varieties of vines studied and the treatments applied in specific climatic conditions, behaved differently from the attack of this pathogen.

Of the group of varieties with higher values of the degree of attack of the phytoparasite Plasmopara viticola, they are part of Tămâioasă Românească with 5.62\% attack on the leaves and Chardonnay with $4.30 \%$ attack on the leaves in the year 2019. In the year 2020, the values were close, lower for the variety Tămâioasă Românească with $5.60 \%$.

Attack the bunches with values between $2.94 \%$ and $2.54 \%$ respectively are included in the year 2019. In the year 2020, the value of the degree of attack on the bunches was more low, compared to year 2019 for Tămâioasă Românească respectively 2.93\%, while for the Chardonnay the values were the same as in the previous year.

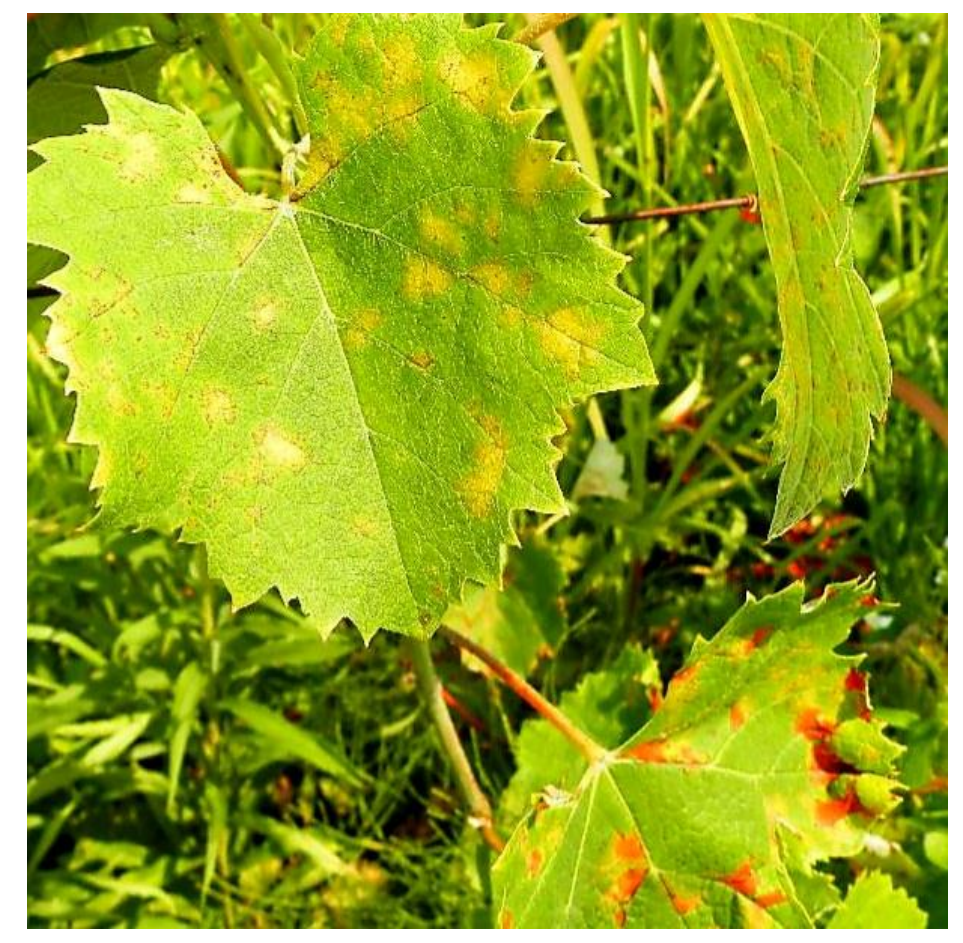

Figure 3. Plasmopara viticola-leaf attack stains undelemnii-original 
Current Trends in Natural Sciences

Vol. 10, Issue 19, pp. 362-367, 2021

https://doi.org/10.47068/ctns.2021.v10i19.047

Current Trends in Natural Sciences (on-line)

ISSN: 2284-953X

ISSN-L: 2284-9521
Current Trends in Natural Sciences (CD-Rom)

ISSN: 2284-9521

ISSN-L: 2284-9521

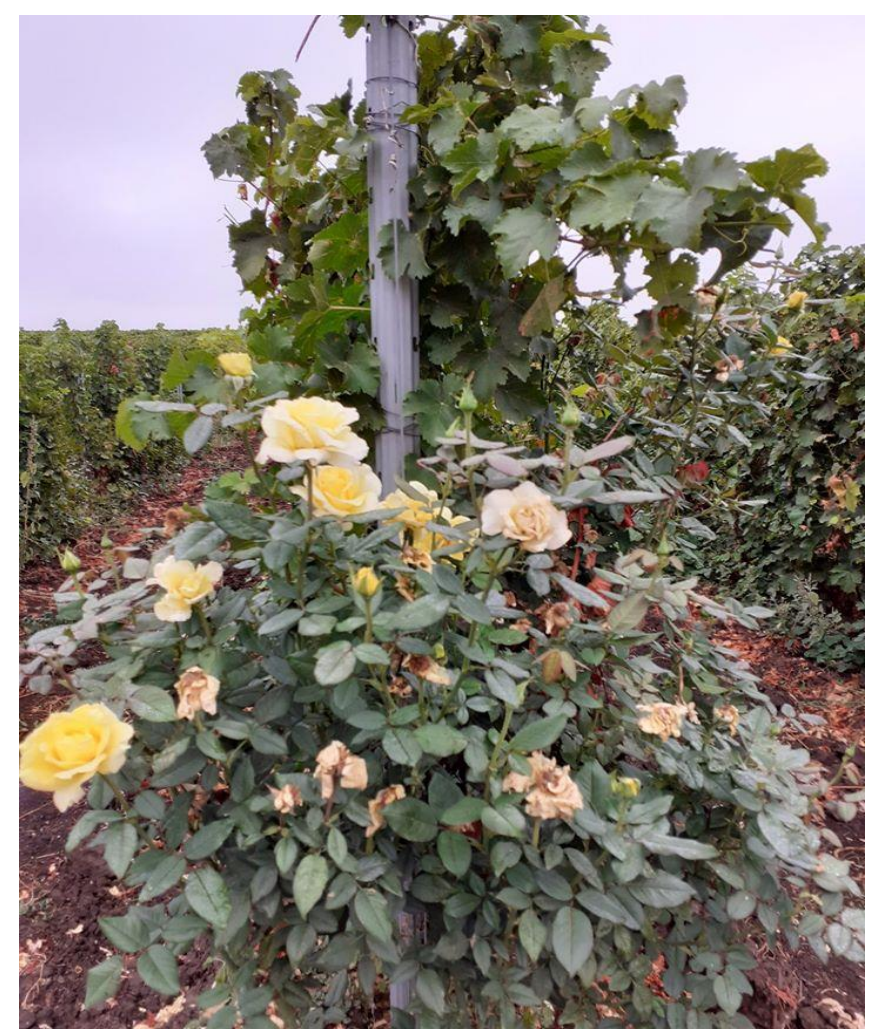

Figure 4. Archdiocese of Craiova - Segarcea wine farm - original

\section{REFERENCES}

Bădărău S., Nicolaescu Olga, Alexei B. (2007). New fungicides approved for the control of the Plasmopara viticola fungus (Berk.et Curt) Berl. et Toni, in Moldavia, Scientific papers, vol. 15(3), Chișinău;

Ianoși Ioan Sigismund (2002). Guide for the use of pesticides approved in Romania in the control of plant pests in crops and in forestry, Ed. a I-a, (vol. I), Ed. Phoenix, Brașov;

Mitrea Rodi (2006). Key diseases of the main horticultural species, Ed. Universitaria, Craiova;

Roșca Ioan (2018). Plant health, USAMVB, Bucharest;

Rădulescu E. et al. (1972). Treatise on Agricultural Phytopathology, vol. IV), R.S.R. Academy Publishing House Romania. 